\title{
The Social Consequences of Legal Principles: Investigating the Origins of Squatting in Sri Lanka's Land Settlement Schemes
}

\author{
Kavindra Paranage, (B.A., LL.B.)
}

University of Colombo, Sri Lanka

doi: 10.19044/esj.2017.v13n26p294 URL:http://dx.doi.org/10.19044/esj.2017.v13n26p294

\begin{abstract}
This research tries to understand the reasons for the continuing presence of squatters in Sri Lanka's state-sponsored land settlement schemes. A preliminary review of the literature pertaining to this area suggests that the legal and regulatory framework in these settlements may be the cause that trigger the necessary social preconditions required for squatter settlements to come into existence. In trying to test this hypothesis found in the literature, the present paper undertakes a qualitative historical analysis into a sample village where squatter settlements are most profoundly observed. Data is collected from three main sources: interviews conducted with key informants in the sample village, focus group discussions conducted with a mixed group of stakeholders as identified through key informants and, an exhaustive analysis of legal documents concerning land ownership and distribution as well as population-related statistics, land utilization patterns and village infrastructure.

The analysis of the data proves the hypothesis as accurate by revealing that the central reason for the existence of squatters in the sample village is the legal restriction pertaining to minimum subdivisions by virtue of the Land Development Ordinance (1935) among other statutory provisions. This restriction prohibits owners from apportioning title to their land; they may only transfer title subject to the condition that such a transfer will not divide or otherwise fraction the property. Such restrictions serve to create a 'social space' where a number of second and third generation settlers are effectively left without a lawful claim to land, with encroaching on their siblings' property or government property becoming the only available recourse.
\end{abstract}

Keywords: Land ownership, squatter, stream reservation 


\section{Introduction}

Sri Lanka is an island in the Indian Ocean spanning an extent of 65,525 square kilometers and containing 103 river basins. The population of

Sri Lanka is approximately 21 million, over 75 percent of which is resident in rural areas. About 33 percent of the population is engaged in various agriculture-based forms of employment. The pattern of life in Sri Lanka depends directly on the obtainability of rainwater. The mountains and the southwestern part of the country, known as the wet-zone receive abundant rainfall: an annual average of 2500 millimeters. Most of the southeast, east, and northern part of the country comprise the dry-zone which, in contrast, only receives between 1200 and 1900 millimeters of rain annually. Much of the rain in these areas falls from October to January; during the rest of the year there is very little precipitation, and all living creatures must conserve precious moisture.

\section{Land settlement}

From the early $20^{\text {th }}$ century onwards the government of Sri Lanka has placed great emphasis in settling people in certain particular areas of the dryzone according to various formal plans devised by several government agencies. These formal settlements created as a matter of policy is conceptually defined as "state-sponsored land settlement schemes" (hereinafter abbreviated to SLSS) for the purpose of the present study and is the backdrop relating to our discussion of squatter settlements. A brief quasihistorical digression regarding the development of SLSS with particular focus on their regulatory framework and the settlement dynamics is necessary prior to concentrating our attention to the problem squatter settlements alone.

According to Peter C. Bloch (1988), how land is granted, transferred and owned within SLSS is governed by two legal ordinances and an authority called the 'Land Commission'. The first Land Commission, according to Bloch, was established in 1927 and, in 1935, the first Land Development Ordinance was passed. This 'Land Development Ordinance of 1935' and the 'Crown Land Ordinance of 1840' together outline the system of permits and grants which regulate an individual's access to land within the SLSS. Lands are distributed at institutions called 'Land Kachcheries'. Successful applicants receive permits to occupy land, and have to pay an annual sum to retain the permit. After the land is developed (i.e. cultivated), the holder is eligible to obtain a grant, which is issued after the land has been completely surveyed. The grant is then registered with a 'Government Agent'. While the grant has numerous characteristics of a property title and the occupier is called the "owner of the holding" the land is still considered 
to be state-land, because the grant holder cannot transfer title, or lease or mortgage the land without the authorization of the Land Commissioner.

Within the SLSS, in addition to distributing state owned land the government likewise provided infrastructure facilities such as irrigation, roads and other common amenities as well as the social infrastructure necessary to start life in these new settlements. Even the type of land given under SLSS comprise both 'residential-type lands' as well as 'cultivation lands'. Over the years, the amount of land distributed per household was reduced. As land became scarce, settlers were given smaller plots of land. Until 1953 the norm was 5 acres of wetland and 3 acres of highland. In 1953 this was further reduced to 3 acres of wetland and 2 acres of highland, and in 1956 it was reduced yet again to 2 acres of wetland and 1 acre of highland. Presently, the standard allocation is 2.5 acres of paddy and 0.5 acres of homestead (Manchanayaka and Madduma Bandara 1999).

An inherent feature of SLSS is the establishment of a highly centralized government authority to implement them. This also means a high degree of governmental control. In other words, it is clear that SLSS are not traditional villages, but bureaucratically controlled entities, which in turn form part and parcel of a very centralized state (Bastian 2008). For instance, the cultivatable land plots given to people are organized in a particular way to suit centralized water supply.

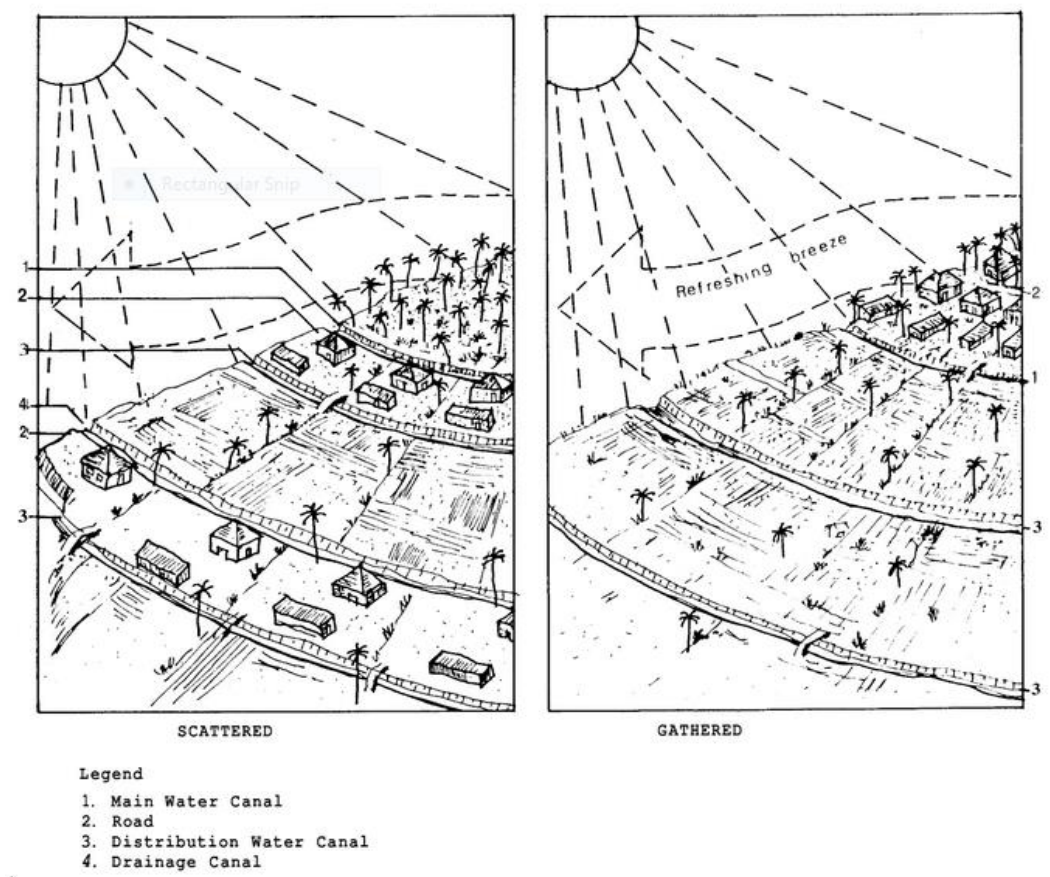

Fig 1: Distribution of land plots in SLSS (Source: Weitz et. al. 1971) 
Thus, if an owner were to cultivate in his or her piece of land, he or she would have to cultivate according to a cultivation timetable approved by a government agency; therefore, what is cultivated when is a matter that is not subject to much leeway or personal discretion.

\section{Squatter settlements within the SLSS}

The rise of squatting within the colonized public lands constituting the SLSS has long been the subject of much discussion in the literature. For instance, Abeysekara (1986) notes that in Mahavilachchiya irrigates settlement scheme in Anuradhapura District, there were 900 authorized allotments if 5-acre units and about 250 illegal squatter settlements. In Gal Oya, Kobbekaduwa, Razaak, and Perera (1995) cites the example of the Uhana/Mandur Branch Canal, in which 1,175 hectares was land encroached on by squatters. The way in which squatters contribute to a number of social problems has also been widely discussed. Farrington and Abeyratne (1982:41) suggests that squatters may be tapping water from unauthorized parts of the irrigation system, resulting in tail end farmers receiving water shortages. These findings are also confirmed by Gunadasa (1982:65) who found similar effects on his study of squatters in 'Hakwatuna Oya' and 'Kimbulwana' irrigated SLSS. In a number of other SLSS areas, Tilakasiri (1985:47) notes that "with more area than planned being cultivated [by squatters], the demand for water is increased". Ranatunge, Farrington and Abeysekara (1981) also document a variety of irrigation-related problems associated with the rise of squatter settlements in SLSS.

Despite squatter settlements being the subject of such discussion, hardly any thought has been given in the literature to the reasons for squatter settlements to originate in the first place, save by Chandrasekara and Gunawardena (2011) in their study on encroachments in stream reservations and previously by Pamela Stanbury (1988). A review of their work suggests that squatting may be broadly related to the legal framework of inheritance that governs the SLSS. The findings of Bloch (1988) cited earlier within this work regarding how land is granted, transferred and owned within SLSS coupled with the suggestion of Bastian (2008) that the legal and regulatory framework within SLSS subjects its residents to a high degree of government control can also be used to support this hypothesis to a certain degree.

However, question still remains as to the precise manner in which squatting can be connected to the legal framework that govern SLSS. For this reason, conducting a proper investigation as to the sources of legal regulations that govern SLSS as well as effecting a substantive empirical assessment of the validity of this hypothesis in relation to a specific SLSS settlement with an identifiable squatter problem is fundamental. It should 
also be noted that such an attempt has never been recorded in the literature concerning this topic.

\section{Contribution and scope of the present study}

As stated above, this research attempts to satiate a discernable gap in the literature by testing the hypothesis previously suggested: that the creation of squatter settlements may be related to the laws of inheritance and succession governing the SLSS. In testing this hypothesis, the study identifies two broad researchable questions as its points of departure:

1. To what extent does the legal framework of property inheritance established in SLSS create a 'legal space' that fosters the growth of squatting?

2. How does such a 'legal space' manifest a corresponding 'social configuration' necessary for squatter settlements?

\section{Methodology}

In responding to the questions set above, the study embodies a multifaceted research design that undertake both a documentary analysis as well as an empirical investigation into the topic. In relation to the first limb of the research (RQ-1) a review of the major ordinances, statues and other relevant legislation is undertaken to illuminate the legal backdrop of land inheritance within the SLSS. In relation to the second limb (RQ-2) the research undertakes empirical investigations in a sample village that forms part of the SLSS, settled under the Mahaweli Development Programme.

The sample village (the identity of which shall remain anonymous given the legal sensitivity of the subject matter) is one of eight near-identical villages in the North Central Province of Sri Lanka. It is one of the villages to be completely subject to state-sponsored land settlement by the Ministry of Mahaweli and Environment of the Sri Lankan government as early as 1978. Several generations have passed since the original settlements were created as part of the SLSS. In terms of social demographics, the village can be considered as stereotypical of the majority of villages constituting the SSLS. Further it is a village in which well-defined areas of squatter settlements can be observed.

The methods of empirical inquiry undertaken in this area include 20 interviews conducted with key informants (government officers pertaining to the administration and enforcement of laws in the SLSS such as the police, officers of the Mahaweli Authority and the Ministry of Irrigation and Water Resources Management etc.) in the sample village, as well as 3 focus group discussions (participation rates set between 8-12 per discussion) conducted with a mixed group of stakeholders (tenured landholders and squatters) as identified through key informants. The findings of the focus groups were 
also complemented by several more informal discussions that were conducted with a variety of stakeholders. These qualitative empirical inquiries were positioned so as to understand how the legal framework intersect and affects the life of ordinary people; to understand the social cost and consequences of implementing the existing regulatory framework that governs the SLSS. In this sense, the regulatory framework and associated institutions are considered as 'social agents' that has the ability to affect the lives of the people living in SLSS in a myriad of ways (studies employing similar methodologies can be found in Ferguson 1990, and Escobar 2011, concerning the development problematic). The central question that the empirical queries seek to grapple with can be stated as: "what happens differently due to the implementation of the 'laws' that make up the regulatory framework?'

\section{Findings}

The key research findings shall be divided and discussed in relation to the two researchable questions posed: the first part discussing the major legislation (ordinances and statues) that defines how land should be occupied in SLSS, and the subsequent part reviewing the findings attained from empirical investigations.

\section{Reviewing the legal framework for SLSS}

In reviewing the legal framework for SLSS, it is necessary to begin from the colonial period, where legislation for Sri Lanka was subsumed under the sovereignty of the British crown. The most important statute in this context is the Crown Land (Encroachment) Ordinance of 1840, which sets the basis for the regulation of all state lands including SLSS. This ordinance, first enacted in 1849 and revised thereafter to its latest form in 1949, gave the crown the right to take over any uncultivated land and to grant, sell or lease such lands to individuals or institutions "for any purpose which the Governor-General may approve." As such, all forest, waste, unoccupied or uncultivated lands (the majority of which were located in the country's dryzone) were presumed to be Crown property until the contrary was proved. This presumption in favor of the crown was very strong, so that very few peasants could win cases of land disputes against the crown.

The legal situation created by this ordinance is of extreme importance, since it identifies and delineates certain portions of lands in Sri Lanka as "crown lands" (later styled as "state lands"). The legal framework that govern these "crown lands" are very different to the usual laws that govern land ownership, commonly referred to as "Fee Simple Absolute in Possession" or FSAP (Bruce 1998). According to Dixon (2010) FSAP lands give their owners the right to divide, distribute, lease or otherwise alienate 
these lands in any manner of their choosing; in other words, their ownership is largely unencumbered. Crown lands, in contrast, operates according to a different set of rules, and imposes severe limitations on the occupier, as will be described later.

The second major development in the legal framework arrived in the form of the Land Development Ordinance of 1935 (hereinafter abbreviated to LDO 1935) which reflects the increasing concern for improving the position of the peasant cultivator. For the first time, the government sought to alienate crown lands to several classes of settlers, most notably cultivators. It should be noted that the legal principles that underlie the creation of SSLS all stem from the framework created by this ordinance, as state-sponsored land settlements are, in fact, a variety of crown lands alienated to a specified class of persons. As such, ownership of these lands is replete with various encumbrances: the land "cannot be sold leased or mortgaged, either in part or whole without the written consent of the government agent". If a grantee failed to abide by any of these encumbrances, the grant/permit of the land parcel could be cancelled.

Another notable finding in relation to the LDO 1935 is that it gives the government agent (acting on behalf of the crown) the right to impose any additional conditions to the piece of land being alienated (in accordance with section 35, 37, and 48A subsection 1 of LDO 1935). Thus, it is possible for the state to introduce specific rules to the grantee in relation to the land parcel being alienated. Although not directly addressed in their work, both Pfaffenberger (1988) and Wattage and Mardle (2005) has demonstrated that the crown often introduces such rules to preserve certain policy purposes.

Herein lies the crux of the matter: in the case of SLSS, the state has often used this feature of the LDO 1935 to introduce a very specific condition attached to the land so distributed: the rule of minimum subdivisions. As Pfaffenberger (1988) notes, land fragmentation is assumed to reduce agricultural outputs and this could not be allowed within SLSS as the policy purpose of creating SLSS was to promote agriculture. Thus, settlers who receive land under SLSS are also privy to the rule of minimum subdivision introduced under the LDO 1935, settlers in SLSS cannot divide ownership of the lands that they live in and cultivate, and pass it on to more than one person in smaller pieces - it must be passed on as a whole to a single successor.

As we shall see from our empirical observations, this condition often translates into the central cause for the creation of squatter settlements. It should also be noted that this imperative to introduce the rule of minimum subdivisions is also entrenched in the Irrigation Ordinance of 1946, the Paddy Lands Act of 1958, as well as in the Report of the Land Commission 1958 (Sessional Paper X, September 1958). 


\title{
The social consequences of legal principles
}

We now turn to an analysis of the social experience created within the legal configuration determined for SLSS by the LDO 1935. Data obtained from the key informant interviews conducted with administrative officers such as the manager of the settlements unit wherein the sample village is contained reveal that the rule of minimum subdivisions (discussed above) is the de-facto cause for the creation of squatters in the sample village, as well as in the majority of settlements that constitute the statesponsored land settlement schemes. As one officer explains:

\begin{abstract}
"... these [rules of minimum subdivisions] has the inevitable result of squatters being created. If a person, one of the first settlers, has many children, usually he will try to divide up his land ... the problem in settlements is that you can't really divide up the land without state permission and the state doesn't want to give permission, because increasing land fragmentation is reducing cultivation output. Also, the procedure for obtaining permission is long and complicated and few people are willing to follow through, let alone be confident of the chances of their application. So when the land owner passes away, only one son can really inherit the property. The others are mostly reduced to squatting on either their siblings' land or in reservation areas..." [field notes, translated].
\end{abstract}

As can be seen, the rule of minimum subdivisions being strictly enforced in order to maximize agricultural potential within SLSS creates a situation where the majority of the second and third generation of settlers have no alternative but to become squatters on either their siblings' property or on areas reserved by the government. This is further confirmed by analyzing the documents pertaining to settler families, village infrastructure and squatters as recorded by the project offices tasked with administering SLSS. All these documents demonstrate that land owning families have been resident in the sample village for longer periods than squatters. This demonstrates that the creation of squatter settlements is ongoing, while the number of land-owning families remain static.

\begin{tabular}{|c|c|c|}
\hline Years settled & Owner families & Squatter families \\
\hline$<5$ years & 0 & 9 \\
\hline 6-10 years & 0 & 8 \\
\hline ears & 7 & 4 \\
\hline$>20$ years & 49 & 0 \\
\hline
\end{tabular}

Source: LC-105 registry for the village, obtained by the unit manager

However, in continuing the interviews and reviewing the sociodemographical profile of the sample village via the census of population and housing in Sri Lanka for 2012, several factors that contribute to the exacerbation of the squatter problem come into light: 
"... The people in these settlements are trained for farming. Initially, willingness to be cultivators was the qualification sought by the government for being a settler, what was the point of having non-farming families in a settlement created to promote agriculture? Also, the children of these families don't receive a good education, what they know is about farming. If one had money, one doesn't need to be a squatter, of one had education or interests other that agriculture, they can pursue better prospects. But children from these areas usually don't have the time, money or inclination to go away and live somewhere else, they don't know enough to get a job that will take them out of town ..." [field notes, translated].

As this discussion indicates, the fact that the social world of these children is centered around agriculture, the lack of achievement or aspirations in formal education, the lack of collateral assets and presumably the lack of savings and other financial assets limit their pathways to seek their livelihood outside the village. These factors all collaborate with the regulatory framework governing SLSS to create a 'social space' where squatter settlements are formed and fosters.

The preceding paragraphs demonstrate a creation of a 'social space' for the squatter settlements to develop. However, it would be a mistake to assume that the space thus created is homogenous. From a socio-legal standpoint, it can be observed that the type of land that landless people decide to erect structures on, and the way they maneuver within the social space are also vastly different from each other depending on a large number of differing variables. According to the dialogue that emerged from the focus group and informal discussions:

"... there is more than one way that people squat on lands that do not belong to them. Of course, their choice depends on a lot of factors. Where, for instance, the family ties are strong, the person who is left without land will often occupy part of their siblings' [who holds legal title to the lands] property with their express or implied consent. Some others set up informal arrangements with a land owner that allows them to stay or cultivate on the lands in exchange for money or services. Still others camp out on the reservation areas in the canals issuing from the village tank ..." [field notes, translated].

As can be seen then, different people react differently to the problems they encounter due to the lack of land ownership, presumably based on a number of social factors, such as the strength of kinship ties, etc. The focus group as well as informal discussions with the community also suggests that there can be (at least) three different ways to classify squatters by their relationship to the laws of land ownership:

1. Those who occupy a part of their siblings' property,

2. Those who enter into quasi-legal arrangements with land owners, and 
3. Those who encroach on the reservation areas in the catchment area of the sample village tank; the main source of water for cultivation in the area.

The presence of squatters in the third category leads to various negative consequences for the water resources, one of which is that since squatter-cultivators are illegal occupiers of lands they are not entitled to be part of the official water supply framework (which we noted was centrally determined and reguated by the state). Since such non-entitlement policies effectively prevent them from cultivating and thereby earning a livelihood, the situation leads them to respond by creating various other alternate means of getting water, often at the expense of the existing hydraulic structures. It should be noted that this finding broadly tallies with the various observations noted in the literature pertaining to SLSS in Sri Lanka discussed in the preceding sections of this research. To quote one key informant:

“... squatters contribute to an increase of people involved in decision-making and create difficulties [with respect to water management] of orchestrating water supplies due to the sheer numbers. Also, they are not officially recognized so that they cannot formally participate in management. On occasion, they cause disharmony and conflict by misusing irrigation water. It is, actually, a rather frequent complaint that squatters obstruct the water channels by creating inlets into their own cultivation plots and so reducing the amount of water that goes into the official farm lands ..." [field notes, translated].

\section{Conclusion:}

The aim of the present study was to explore the connection between the creation of squatter settlements in SSLS and the regulatory framework that governs land ownership, by means of a qualitative historical analysis of the legislature governing the SSLS and empirical datasets obtained from a sample village. The data examined reveal that it is the rules of succession, inheritance and transference pertaining to land as determined by the LDO 1935 that creates the necessary preconditions for squatter settlements to occur and grow within SSLS. A number of social forces that contributed to a growth of the settlements has also been identified, along with the different conformations of the squatter settlements. It is suggested that a full-scale revision of the regulatory framework is necessary for this tenacious issue to be resolved.

\section{References:}

1. Abeysekara, W. A. T. (1986). Improvement of irrigation system performance in Sri Lanka: the experience at Mahavilachchiya Settlement. Cornell University. 
2. Bastian, S. (2008). The politics of land reform and land settlement in Sri Lanka. International Centre.

3. Bloch, P. C. (1988). Land tenure issues in Sri Lanka: A brief overview. Land Tenure Center, University of Wisconsin--Madison.

4. Bruce, J. W. (1998). Review of tenure terminology. Land Tenure Center, University of Wisconsin-Madison.

5. Chandrasekara, S. S. K., \& Gunawardena, E. R. N. (2011). Effectiveness of Existing Laws and Regulations to Prevent Encroachments of Stream Reservations. Tropical Agricultural Research, 22(2).

6. Dixon, M. (2013). Modern land law. Routledge.

7. Escobar, A. (2011). Encountering development: The making and unmaking of the Third World. Princeton University Press.

8. Farrington, J., \& Abeyratne, F. (1982). Farm power and water use in the dry zone [of Sri Lanka]. Research Study-Agrarian Research and Training Institute (Sri Lanka).

9. Ferguson, J. (1990). The anti-politics machine:'development', depoliticization and bureaucratic power in Lesotho. CUP Archive.

10. Gunadasa, J. M. (1982). Problems of settlement agriculture. Land Settlement Experiences in Sri Lanka, US-AID/Ministry of Lands and Land Development, Colombo, 58-75.

11. Kobbekaduwa, H., Razaak, M., \& Perera, J. (1995). Water-user organizations in irrigation water management in the Gal Oya left bank irrigation system.

12. Manchanayaka, P., \& Bandara, C. M. (1999). Water resources of sri lanka (No. 4). National Science Foundation.

13. Pfaffenberger, B. (1988). Fetishised objects and humanised nature: towards an anthropology of technology. Man, 236-252.

14. Ranatunga, A. S., Abeysekara, W. A. T., \& Farrington, J. (1981). Some Issues Confronting the Rehabilitation of Major Irrigation Schemes in the Dry Zone. Agrarian Research and Training Institute.

15. Stanbury, P. (1988). Land settlement planning issues in irrigation management: A review of experiences in Sri Lanka. IWMI.

16. Tilakasiri, S. (1985). Below the Outlet: A study of Settler Adaptation to Irrigation Water Use in the Mahaweli Development Scheme, Sri Lanka (unpublished master of social studies dissertation submitted to the Department of Water in Environment and Society. University of Linkoping.

17. Wattage, P., \& Mardle, S. (2005). Stakeholder preferences towards conservation versus development for a wetland in Sri Lanka. Journal of Environmental Management, 77(2), 122-132. 
18. Weitz, R. (1971). From peasant to farmer: A revolutionary strategy for development. Columbia University Press. 